\title{
KUALITAS MAKANAN JAJANAN TEMPURA \\ DI SDN BOGEM I SUKOMORO-MAGETAN TAHUN 2014
}

Ernawati, Budi Yulianto, Lilis Prihastini

\begin{abstract}
Tempura is a kind of snack well liked by children because they are delicious and its inexpensive. Being so inexpensive there is always a possibility that some aspects of food quality are compromised. This research was intended to learn on the quality of tempura snacks on the basis of their physical, chemical and microbiological aspects.

This was considered as a descriptive research, focusing on the quality of tempura snacks sold by vendors in the vicinity of SDN Bogem I, to be riviewed from physical aspects (color, smell, taste, and texture), chemical (borax and formalin) and microbiological aspects (bacterial count). The population to be studied were all tempura snacks sold by vendors in the vicinity of SDN Bogem I. In this research 3 samples of tempura snacks were taken. These samples were selected using simple random sampling.

The result indicated that the physical quality of all sample were poor. On inspection of chemical quality all samples were positive for borax and formalin contents. Examination of the bacterial count on samples tempura snacks resulted in a mean of sample 1 as 493.3 colonies/gram, sample 2 was 133.7 colonies/gram and sample 3 was 560 colonies/gram. Therefore, according the quality standard designated in Surat Keputusan Kepala Badan POM RI No. HK.00.06.1.52.4011 Tahun 2009 Tentang Penetapan Batas Cemaran Mikroba dan Kimia Dalam Makanan, that is 100,000 colonies/gram, this meant that sample 2 exceeded the limit.

This research concluded that based on their physical, chemical and microbiological aspects, tempura snacks sold by vendors in the vicinity of SDN Bogem I, kecamatan Sukomoro kabupaten Magetan should be disqualified for consumption. The study is warning the community to be more selective and taking a good care in buying of snacks, specially of tempura snacks.
\end{abstract}

Keywords: food quality, snacks, Tempura.

\section{PENDAHULUAN}

Makanan jajanan di sekolah merupakan masalah yang perlu menjadi perhatian masyarakat, khususnya orang tua, pendidik, dan pengelola sekolah. Makanan Jajanan sekolah sangat beresiko terhadap cemaran fisik, kimia dan biologis yang banyak mengganggu kesehatan, baik jangka pendek maupun jangka panjang (Februhartanty dan Iswaranti, 2004).

Kejadian Luar Biasa (KLB) keracunan makanan di Jawa Timur masih sangat tinggi dari tahun ke tahun. Pada tahun 2012, jumlah kejadian KLB mencapai 60 kejadian keracunan makanan dengan 1.106 kasus dan angka case fatality rate (CFR) 0,27\%. Dibandingkan dengan tahun 2011 , jumlah kasus keracunan makanan cenderung meningkat (Dinkes Prop. Jatim, 2013).

Di Kabupaten Magetan setiap tahun selalu terjadi KLB keracunan makanan, kasus keracunan makanan yang terjadi pada tahun 2013 adalah 9 kejadian dengan makanan penyebab keracunan terbesar yaitu jenis makanan jajanan dengan korban anak-anak SD (Dinkes Kab. Magetan, 2013).

Tempura merupakan makanan yang terbuat dari daging giling, sayuran dan tepung serta bumbubumbu yang dicampur jadi satu, dicetak dan digoreng. Jajanan tempura baru ada beberapa tahun ke belakang. Sekarang ini banyak produsen tempura yang menjual dengan harga yang murah. Akan tetapi dengan harga yang murah tadi kualitas makanan jajanan tempura patut diwaspadai keamanannya bagi kesehatan, khususnya bagi kesehatan anak-anak (Hapsari, Reny Andhika, 2011).

Sekolah Dasar Negeri (SDN) Bogem I adalah Sekolah Dasar yang terletak di Desa Bogem, Kecamatan Sukomoro, Kabupaten Magetan. Selain SD di Lingkungan SDN Bogem I juga ada Taman Kanak-Kanak (TK) Dharma Wanita Desa Bogem. Secara geografis SDN Bogem I lokasinya tidak jauh dari SDN Banjarejo II Kecamatan Panekan yang pada tanggal 4 Oktober 2012 terjadi KLB keracunan makanan jajanan tempura. Jumlah siswa keseluruhan di SDN Bogem I sebanyak 84 siswa dan TK Dharma Wanita Desa Bogem sebanyak 32 siswa. Setiap hari siswa-siswi SD dan TK membeli makanan jajanan yang dijajakan oleh pedagang keliling yang berjualan di lingkungan sekolah. Ada 8 pedagang keliling yang biasa mangkal di lingkungan SDN Bogem I. Jenis makanan jajanan yang dijajakan salah satunya adalah tempura. Makanan jajanan tempura merupakan salah satu makanan jajanan favorit siswa-siswi di lingkungan SDN Bogem I. Ada 3 pedagang keliling yang berjualan tempura yang biasa mangkal di lingkungan SDN Bogem I. Alasan siswa-siswi suka mengkonsumsi makanan 
jajanan tempura karena rasanya enak dan harganya murah.

Berdasarkan hasil observasi awal dengan metode organoleptik diketahui bahwa makanan jajanan tempura yang dijual oleh pedagang keliling di lingkungan SDN Bogem I yaitu warnanya coklat muda agak pucat, teksturnya agak kenyal, bau agak amis khas ikan dan rasanya asin gurih. Sedangkan berdasarkan hasil uji pendahuluan di Laboratorium Prodi D-III Kesling Kampus Magetan, Jurusan Kesehatan Lingkungan, Poltekkes Kemenkes Surabaya terhadap angka kuman pada makanan jajanan tempura diperoleh hasil 120.000 koloni/gram. Menurut Baku Mutu Surat Keputusan Kepala Badan POM RI No.HK.00.06.1.52.4011 Tahun 2009 tentang Penetapan Batas Cemaran Mikroba dan Kimia Dalam Makanan, yaitu 100.000 koloni/gram, berarti angka kuman pada makanan jajanan tempura melebihi baku mutu (BPOM, 2009).

Tujuan Penelitian adalah mengetahui kualitas makanan jajanan tempura yang dijual pedagang keliling di lingkungan SDN Bogem I Kecamatan Sukomoro Kabupaten Magetan ditinjau dari aspek fisik, kimia dan mikrobiologi.

\section{METODE PENELITIAN}

Jenis Penelitian adalah deskriptif yang akan menggambarkan kualitas Jajanan Tempura menurut keadaan fisik, kimia dan mikrobiologis nya..

Objek penelitian adalah seluruh makanan jajanan tempura yang dijual pedagang keliling yang biasa mangkal di lingkungan SDN Bogem I Kecamatan Sukomoro Kabupaten Magetan.

Populasi dalam penelitian ini adalah seluruh makanan jajanan tempura yang dijual pedagang keliling yang biasanya mangkal di lingkungan
SDN Bogem I Kecamatan Sukomoro Kabupaten Magetan

Dalam penelitian ini makanan jajanan yang dipilih sebagai sampel adalah tempura, dengan pertimbangan: 1) Jenis makanan jajanan ini paling banyak dikonsumsi siswa, 2) dari aspek mikrobiologi tidak memenuhi syarat.

Besar sampel penelitian ini yaitu sebanyak 18 sampel jajanan tempura untuk pemeriksaan kimia, dan mikrobiologi. Pengambilan sampel yaitu secara acak sederhana atau simple random sampling.

Kenampakan, Bau, Rasa, Tekstur, Boraks, Formalin dan Angka Kuman.

Teknik Pengumpulan Data dengan Wawancara dan Observasi. Pengambilan Sampel Jajanan diperlukan untuk pemeriksaan Laboratorium.

Analisis Data dilakukan secara deskriptif dengan membandingkan hasil yang diperoleh dengan standard Nasional Indonesia Nomor 01-2346 tahun 2006 tentang Petunjuk Pengujian Organoleptik dan atau Sensori serta Baku Mutu Surat Keputusan Kepala Badan POM RI No.HK.00.06.1.52.4011 tahun 2009 tentang Penetapan Batas Cemaran Mikroba dan Kimia dalam Makanan.

\section{Hasil Penelitian dan Pembahasan}

1. Hasil Pemeriksaan Kualitas Fisik

Berdasarkan tabel 1 hasil rekapitulasi kualitas fisik melalui uji deskriptif, uji hedonik dan uji skor pada 3 sampel makanan jajanan tempura, dari uji deskripsi rata-rata kenampakan putih agak pucat, bau ikan dan agak berbau bahan kimia, rasa gurih agak asin dan manis, tekstur kenyal agak kasar. Sedangkan hasi! pemeriksaan uji hedonik dan skor nilai rata-rata yang ditunjukkan di bawah 7,0 seperti pada tabel berikut.

Tabel 1: Hasil Rekapitulasi Kualitas Fisik Makanan Jajanan Tempura, 2014

\begin{tabular}{|c|c|c|c|c|c|}
\hline \multirow[t]{2}{*}{ No } & \multirow[t]{2}{*}{ Sampel } & \multicolumn{3}{|l|}{ Hasil Uji } & \multirow{2}{*}{ Keterangan } \\
\hline & & Deskripsi & Hedonik & Skor & \\
\hline 1 & I & $\begin{array}{l}\text { Kenampakan putih agak pucat, bau ikan dan agak } \\
\text { berbau bahan kimia, rasa gurih agak asin, tekstur } \\
\text { kenyal agak kasar. }\end{array}$ & 5 & 4,67 & Tidak Baik \\
\hline 2 & II & $\begin{array}{l}\text { Kenampakan coklat agak putih pucat, bau ikan } \\
\text { dan agak berbau bahan kimia, rasa gurih agak } \\
\text { manis dan asin, tekstur kenyal agak kasar. }\end{array}$ & 4,5 & 4,67 & Tidak Baik \\
\hline 3 & III & $\begin{array}{l}\text { Kenampakan putih pucat, bau ikan dan agak } \\
\text { berbau bahan kimia, rasa gurih agak manis, } \\
\text { tekstur kenyal agak kasar. }\end{array}$ & 4,6 & 5,67 & Tidak Baik \\
\hline \multicolumn{2}{|c|}{ Rata-rata } & \multicolumn{2}{|l|}{$\begin{array}{l}\text { Kenampakan putih agak pucat, bau ikan dan agak } \\
\text { berbau bahan kimia, rasa gurih agak asin dan } \\
\text { manis, tekstur kenyal agak kasar. }\end{array}$} & 5 & Tidak Baik \\
\hline \multicolumn{3}{|c|}{$\begin{array}{l}\text { Berdasarkan tabel di atas hasil rekapitulasi } \\
\text { kualitas fisik secara menyeluruh pada } 3 \text { sampel } \\
\text { makanan jajanan tempura melalui uji deskriptif, } \\
\text { uji hedonik dan uji skor, semua sampel termasuk } \\
\text { pada kriteria tidak baik. }\end{array}$} & \multicolumn{3}{|c|}{$\begin{array}{l}\text { Dari uji deskripsi rata-rata kenampakan putih } \\
\text { agak pucat, bau ikan dan agak berbau bahan } \\
\text { kimia, rasa gurih agak asin dan manis } \\
\text { sedangkan tekstur kenyal agak kasar. } \\
\text { Sedangkan hasil pemeriksaan uji hedonik dan } \\
\text { skor nilai rata-rata yang ditunjukkan dibawah } \\
7,0 \text {. }\end{array}$} \\
\hline
\end{tabular}


Hasil Pemeriksaan Kualitas Kimia

Berdasarkan tabel 2 dapat dilihat bahwa 3 sampel makanan jajanan tempura yang diperiksa semuanya positif mengandung boraks dan formalin sehingga termasuk kriteria tidak baik.

Tabel 2: Hasil Rekapitulasi Kualitas Kimia Pada Makanan Jajanan Tempura, 2014

\begin{tabular}{cccccc}
\hline \multirow{2}{*}{ No. } & \multirow{2}{*}{ Sampel } & \multicolumn{2}{c}{ Hasil Pemeriksaan } & \multirow{2}{*}{ Baku Mutu } & \multirow{2}{*}{ Keterangan } \\
\cline { 3 - 4 } & I & Boraks & Formalin & & Tidak Baik \\
\hline 1 & II & Positif & Positif & Negatif & Titak Baik \\
\hline 2 & III & Positif & Positif & Negatif & Tidif \\
\hline 3 & Rata-rata & Positif & Positif & Negatif & Tidak Baik \\
\hline
\end{tabular}

Berdasarkan hasil pemeriksaan kualitas kimia pada makanan jajanan tempura, semuanya termasuk pada kriteria tidak baik untuk dikonsumsi karena semua sampel positif mengandung boraks dan formalin. Berdasarkan Permenkes RI Nomor 33 Tahun 2012. tentang Bahan Tambahan Pangan : Boraks dan Formalin merupakan Bahan Tambahan Pangan yang dilarang digunakan pada makanan.
Hasil Pemeriksaan Kualitas Mikrobiologi Berdasarkan tabel 3 dapat dilihat bahwa dari sampel I makanan jajanan tempura yang diperiksa rata-rata mengandung angka kuman 493,33 kol/gram. Sampel II rata-rata mengandung angka kuman $133.666 \mathrm{kol} / \mathrm{gram}$. Sampel III rata-rata mengandung angka kuman $560 \mathrm{kol} / \mathrm{gram}$.

Tabel 3: Hasil Pemeriksaan Angka Kuman Pada Makanan Jajanan Tempura, 2014

\begin{tabular}{ccccc}
\hline \multirow{2}{*}{ No } & \multirow{2}{*}{ Pemeriksaan ke } & \multicolumn{3}{c}{ Hasil Pemeriksaan Angka Kuman (Kol/gram) } \\
\cline { 3 - 5 } & 1 & Sampel I & Sampel II & Sampel III \\
\hline 1 & 2 & 450 & 157.000 & 370 \\
\hline 2 & 3 & 410 & 139.000 & 760 \\
\hline 3 & Rata-rata & 420 & 105.000 & 550 \\
\hline & Baku mutu & 193,33 & 133.666 & 560 \\
\hline Keterangan & 100.000 & 100.000 & 100.000 \\
\hline & Baik & Tidak baik & Baik \\
\hline
\end{tabular}

Berdasarkan tabel 3 hasil pemeriksaan mikrobiologi pada 3 sampel makanan jajanan tempura di atas, jika dibandingkan dengan Surat Keputusan Kepala Badan POM RI No. HK.00.06.1.52.4011 Tahun 2009 Tentang Penetapan Batas Cemaran Mikroba dan Kimia Dalam Makanan, sampel I dan sampel III masih memenuhi syarat baku mutu sedangkan sampel II tidak memenuhi syarat baku mutu yaitu $100.000 \mathrm{kol} / \mathrm{gram}$.

Tabel 4: Cross Tabulasi Kualitas Makanan Jajanan Tempura Ditinjau Dari Aspek Fisik, Kimia dan Mikrobiologi

\begin{tabular}{|c|c|c|c|c|c|c|c|c|c|}
\hline \multirow{3}{*}{ No } & \multirow{3}{*}{ Sampel } & \multicolumn{6}{|c|}{ Kategori Kualitas } & \multirow{2}{*}{\multicolumn{2}{|c|}{ Kategori Konsums }} \\
\hline & & \multicolumn{2}{|c|}{ Fisik } & \multicolumn{2}{|c|}{ Kimia } & \multicolumn{2}{|c|}{ Mikrobiologi } & & \\
\hline & & Baik & $\begin{array}{c}\text { Tidak } \\
\text { Baik }\end{array}$ & Baik & $\begin{array}{c}\text { Tidak } \\
\text { Baik }\end{array}$ & Baik & $\begin{array}{c}\text { Tidak } \\
\text { Baik }\end{array}$ & Layak & $\begin{array}{l}\text { Tidak } \\
\text { layak }\end{array}$ \\
\hline 1 & I & & $x$ & & $x$ & + & & & $-v$ \\
\hline 2 & II & & $x$ & & $x$ & & $\mathrm{X}$ & & $-v$ \\
\hline 3 & III & & $x$ & & $x$ & + & & & $-v$. \\
\hline
\end{tabular}

Keterangan $:+=$ Baik, $x=$ Tidak Baik,$v=$ Tidak layak dikonsumsi

Analisis Kualitas Makanan Jajanan Tempura Ditinjau dari Aspek Fisik, Kimia dan Mikrobiologi berdasarkan tabel 4 dapat dilihat bahwa kualitas makanan jajanan tempura ditinjau dari aspek
Analisis Kualitas Makanan Jajanan Tempura Ditinjau Dari Aspek Fisik, Kimia dan Mikrobiologi Berdasarkan tabel 4 dapat dilihat bahwa hasil pemeriksaan fisik secara umum diperoleh hasil tidak baik, pemeriksaan kimia diperoleh hasil tidak baik dan hasil pemeriksaan mikrobiologi angka kuman diperoleh hasil secara umum tidak baik.

fisik, kimia dan mikrobiologi tidak layak untuk dikonsumsi. Berdasarkan SNI Nomor 01-2346

Tahun 2006 tentang Petunjuk Pengujian Organoleptik dan atau Sensori, hasil pemeriksaan 
fisik dengan uji deskripsi, uji hedonik dan uji skor dari 3 sampel semuanya didapat hasil tidak baik. Hasil pemeriksaan kimia semuanya juga mendapatkan hasil tidak memenuhi syarat karena mengandung Boraks dan Formalin sedangkan hasil pemeriksaan mikrobiologi yaitu angka kuman, dari 3 sampel 2 di antaranya didapat hasil baik dan 1 sampel hasilnya tidak baik karena melebihi baku mutu yang ditetapkan Surat Keputusan Kepala Badan POM RI No. HK.00.06.1.52.4011 tahun 2009 tentang Penetapan Batas Cemaran Mikroba dan Kimia Dalam Makanan yaitu 100.000 koloni/gram.

\section{KESIMPULAN}

1. Hasil pemeriksaan fisik pada makanan jajanan tempura dari 3 sampel semuanya termasuk dalam kriteria tidak baik.

2. Hasil pemeriksaan kimia pada makanan jajanan tempura dari 3 sampel semuanya positif mengandung Boraks dan Formalin.

3. Hasil pemeriksaan mikrobiologi yaitu angka kuman pada makanan jajanan tempura dari 3 sampel yang diperiksa, 2 sampel termasuk kriteria memenuhi syarat baku mutu dan 1 sampel termasuk kriteria tidak memenuhi syarat baku mutu.

4. Analisis pemeriksaan kualitas makanan jajanan tempura dari aspek fisik, kimia dan mikrobiologi, makanan jajanan tempura yang dijual pedagang keliling di lingkungan SDN Bogem I tidak layak untuk dikonsumsi.

\section{RUJUKAN}

Dinkes Prop. Jatim, 2012. Profil Kesehatan Provinsi Jawa Timur Tahun 2012. Dinas Kesehatan Provinsi Jawa Timur.

Dinkes Kab. Magetan, 2012. Kasus Keracunan Makanan Pada Anak Sekolah. Dinas Kesehatan Kabupaten Magetan, Jawa Timur.

Februhartanty dkk, 2004. Amankah Makanan Jajanan Anak Sekolah di Indonesia. Funna, Rifky Ari, 2013. http://rifky1116058.wordpress.com/2013/01 /09/apa-itu-uji-organoleptik/. Diakses: 9 Januari 2013.

\section{SARAN}

1. Bagi Masyarakat

Masyarakat lebih berhati-hati dan selektif dalam membeli makanan jajanan khususnya makanan jajanan tempura.

2. Bagi Pedagang

Tidak menggunakan bahan kimia Boraks dan Formalin pada makanan.

Menjaga kebersihan peralatan atau perlengkapan yang dipakai.

Menggunakan alat pelindung diri sarung tangan karet atau alat penjepit untuk membatasi kontaminasi langsung dengan makanan jajanan.

Tidak menggunakan minyak berkali-kali untuk menggoreng.

Menjaga suhu tempat penyimpanan tempura yang masih mentah.

3. Bagi Dinas atau Instansi Terkait

Lebih ditingkatkan penyuluhan di masyarakat sebagai konsumen.

Pembinaan terhadap para pengusaha/pedagang/penjaja makanan untuk meningkatkan kualitas makanan jajanan yang beredar di masyarakat.

4. Bagi peneliti lain perlu diteliti lanjut tentang: Kualitas makanan jajanan tempura dari aspek fisik, kimia dan mikrobiologi di lokasi/daerah lain.

Kualitas makanan jajanan selain tempura.

Industri Rumah Tangga (IRT) yang memproduksi makanan jajanan.

Hapsari, Reny Andhika. 2011. Pengaruh Perbandingan Tepung Tapioka dan Tepung Maizena Terhadap Mutu Tempura Ikan Kuniran (Upeneus sulphureus). http://elibrary.ub.ac.id/handle/123456789/2 5071? mode=full diakses: 25 Mei 2011.

Peraturan Kepala Badan Pengawas Obat dan Makanan RI Nomor HK.00.06.1.52.4011tahun 2009 Tentang Penetapan Batas Maksimum Cemaran Mikroba dan Kimia Dalam Makanan.

Permenkes RI Nomor 33 tahun 2012 tentang Bahan Tambahan Pangan.

Standar Nasional Indonesia (SNI) Nomor 012346 tahun 2006 Tentang Petunjuk Pengujian Organoleptik dan atau Sensori. 